\title{
Communication foundation for intellectual culture: tendencies of contemporary development
}

\author{
Yury V. Pushkarev - Elena A. Pushkareva
}

DOI: 10.18355/XL.2019.12.04.18

\begin{abstract}
The article deals with the development of intellectual culture in the conditions of modern communication. The purpose of the article is to determine the basis of the features of the influence of communication factors on the development of intellectual culture in modern society. The methodology of the article is based on the analysis and generalization of research works of foreign and domestic scientists in the field of globalization, communication, information and knowledge development of society, philosophy of education, intellectual development of personality. In the article the authors investigate the following important issues of the impact of communication factors on the development of modern society: What are the global factors of modern society determine the specifics of community communication; Why education today is located in the center of communication what is the main difference between internationalization and globalization of education; Why it is necessary to use the intellectual potential realized in science and education as one of the most important resources for the development of modern society; What changes should be taken into account in the development of intellectual culture as a cognitive system of society.In conclusion, the authors determine what are the main features of the impact of communication factors on the development of intellectual culture in modern society.

Key words: communication factors of development, conditions of modern communication; intellectual culture, development of knowledge society
\end{abstract}

\section{Introduction}

The specificity of modern social development is characterized by the increasing role of means of communication, theoretical knowledge and information technologies (Rodríguez, D., Busco, C., Flores, R., 2015).

Today, communication factors that directly depend on the means and technologies of information exchange are becoming more and more decisive.

Currently particularly relevant are studies of the peculiarities of the influence of communication factors on the development of social systems of society and, above all, the education system (Pisonova, M., 2016) as the main translator of cultural values.

The purpose of the article is to determine the basis of the features of the influence of communication factors on the development of intellectual culture in modern society.

\section{Materials and Methods}

The methodology of the article is based on the analysis and generalization of research works of foreign and domestic scientists in the field of globalization, communication, information and knowledge development of society, philosophy of education, intellectual development of personality.

\section{Results}

\section{Communication and global factors of development of society}

First, let's define what global factors of modern society determine the specifics of community communication.

The modern world is currently in the active process of becoming a global organization of socio-cultural space. 
The processes of globalization are carried out objectively as the social and cultural potential of each society is realized (Kolykhalov, M. I., Pushkareva, E. A., 2018).

Globalization in modern society presupposes the emergence of a single international system that values technological innovations and positive changes in the first place.

The emerging global system is very complex and diverse (Šmajs, J., 2016).

This global system involves peoples and States at different levels of development.

Peoples and States have their own national cultures and traditions, their religious beliefs and beliefs. All this poses many new challenges (Zahid, G., 2015).

The development of transnational corporations and the world financial system, the world network of computer communications is given as examples of the progress of globalization in the modern scientific literature.

Globalization significantly alters the factors of successful social and economic development of society.

In these circumstances, in the first place are considered interrelated with each other:

- ability to technological and social innovation,

- ability to act effectively in a rapidly changing social environment,

- the scale of Informatization of society,

- the level of intellectual and political freedom,

- development of high technologies.

However, modern researchers have little to say about globalization as the process of cultural, social and ideological integration; researchers, for example, discuss the problem of universal values (Pushkarev, Y. V., Pushkareva, E. A., 2018a), but the consensus in the scientific community on this issue did not happen (Pogorletskaia, I. I., 2016).

\section{Education in the center of communication}

The center of the community's efforts for the development of modern communication should be primarily the sphere of education, and then on the basis of developed education it will be possible to develop infrastructure, to occupy competitive positions in the world market of Informatics, microelectronics, telecommunications, etc.

Indeed, in the current socio-cultural situation, education has a great responsibility (Vlasyuk, N. N., Mayer, B. O., 2016).

Russian education operates in the context of trends emerging in the modern world and based on the development of high technologies, global culture, where the continuity of education is understood to follow a specific cultural tradition (Pushkarev, Y. V., Pushkareva, E. A., 2016a).

It is in this context that education is the most important channel for broadcasting both General cultural values and values of national culture, a way of forming a national mentality, a sense of patriotism, involvement in one's roots and origins.

\section{The distinction between internationalization and globalization of education}

A clear distinction must be made between internationalization and globalization of education.

The concepts of internationalization and globalization of education are interrelated and, at the same time, fundamentally different from each other.

Internationalization is the expansion of bilateral and multilateral relations and contacts between universities and other educational institutions of different countries on the basis of equal and mutually beneficial cooperation.

The purpose of internationalization of education is to increase the efficiency of educational and research activities.

The main thing in the process of internationalization of education - bringing it to a higher world level, the expansion of mobility (Brooks, R., 2018) of the teaching staff and students (Shields, R., 2016).

XLinguae, Volume 12, Issue 4, October 2019, ISSN 1337-8384, eISSN 2453-711X 
In the period of increasing interdependence and expansion of relations between States and peoples, the use of the Internet, mobile phones, global telecommunications, distance education-this includes the internationalization of higher education (Khoroshilova, S. P., Kostina, E. A., 2016) (Kostina, E. A., Hackett-Jones, A. V., Bagramova, N. V., 2017).

In other words, internationalization of higher education IS an objective necessity.

Globalization of education is a qualitatively different phenomenon.

Scientists from different countries write that the globalization of education is subordination of education to the interests of the largest transnational corporations that impose their standards of education, their language of communication, do not take into account national characteristics, replace national languages-carriers of original cultures (Mardakhaev, L. V., Egorychev, A. M., Varlamova, E. Yu., Kostina, E. A., 2018).

\section{Intellect, intellectual culture and human capital}

As one of the most important resources for the development of modern society, it is necessary to use the intellectual potential realized in science and education.

Of particular significance for research acquires exactly the concept of human capital (Auer, R. A., 2015).

Today, the concepts of human capital and strategic management of human resources are very common in the organizations is researched scientists for example in terms of philosophy and technique (Pasban, M., Nojedeh S. H., 2016):

The term of "human capital" is considered as a key element in improving the assets of an organization, since it is a sustainable competitive advantage and increases the employees' efficiency. Some organizational theorists apply the rules of human capital theory to prove the ability to create useful competitions between companies by means of developing individual human resources.

In the context of economic development of society, scientists are actively exploring the impact of intellectual culture in the form of human capital on the development of:

- high economic growth of the company (Choi, K.-H., Shin S., 2015),

- the effectiveness of the organization (Latuha, O. A., 2018) (Gogan, L. M., Artene A., Sarca I., Draghici A., 2016).

- countries' economic efficiency (Tzeremes, N. G., 2014).

The impact of intellectual capital on the efficiency of the organization is determined by the following significant factors (Gogan, L. M., Artene A., Sarca I., Draghici A., 2016).

- in the knowledge era, where intellectual capital represents a large part of the value of a product

- In fact, intellectual capital is an important activity for organizations which want to be efficient on the market and thus to obtain sustainable competitive advantage.

The effect of human capital on countries' economic efficiency determined by the relationship between the nonparametric analysis reveal a nonlinear relationship between countries' human capital, technological change and efficiency levels. (Tzeremes, N. G., 2014)

Researchers focus on the balance of three different intellectual capitals: human, social and organizational capitals (Wohlin, C., Šmite, D., Brede Moe, N., 2015).

Thus, the human capital is usually understood as the quantity and quality of physical, intellectual stock of health of the population (Pushkarev, Y. V., Pushkareva, E. A., 2017a) with a guarantee of continuity of generations, preservation of this continuity.

But today, the most important element in the development of modern society is the level of development of its intellectual culture - the quality of education, science and culture, which organize information and intellectual processes that create a qualitatively new person. 
Intellectual culture is understood (Pushkarev, Y. V., Pushkareva, E. A., 2017b) as the culture of society, accumulating, reproducing and creating special information in the form of a system of values (ideas, ideals, traditions, forms and norms of communication and behavior, etc.) as a special environment for the development of society.

\section{The development of new intellectual culture}

The nature of work has changed, in which intellectual work is gaining an increasing share.

Economic activity has significantly changed - its technical base, organizational forms, structure, conditions and requirements that it imposes on the level of knowledge and skills of the employee necessary for the normal functioning of the economy.

In modern conditions, there are new types and activities that lead to changes in demand for the qualification structure of different categories of the population, requiring their professional and social mobility (Şoproni, L., Țoca, C., 2017) (Yonezawa, A., Horta, H., Osawa, A., 2016), continuous education and professional development (Wahlgren, B., Mariager-Anderson, K., Sørensen, S. H., 2016).

In this direction, scientists are actively studying the problems of human resources management(Diaz-Fernandez, M., Pasamar-Reyes, S., Valle-Cabrera, R., 2017), issues of optimal economic policy (Jeong, M., 2015), the impact of human capital on the labor market (Giziene, V., Simanaviciene, Z., 2015) (Guren, A., Hémous, D., Olsen, M., 2015).

Labour market and human capital are interrelated very closely. Human capital consist of knowledge, skills and other characteristics (congenital and acquired), which depends on the individual and is determined by its productivity (Giziene, V., Simanaviciene, Z., 2015).

The recognition that human capital is determined by an individual's ability to meet the labour market conditions, stands for thinking that years spent for studying, attending courses, training and others are appropriate investment for future - for the development of human capital (Giziene, V., Simanaviciene, Z., 2015).

\section{Knowledge as a leading intellectual basis for the development}

Knowledge is the leading intellectual basis (Pushkarev, Y. V., Pushkareva, E. A., 2016b) for the integrative interaction of education and science in the modern global information society.

The integrating function of knowledge is the integration of useful information in order to obtain specific significant results in the process of practical interaction of educational and scientific spheres (Pushkarev, Y. V., Pushkareva, E. A., 2018b).

The specificity of the modern development of knowledge lies in the active influence on the processes of their interaction of communication and information determinants, causing an increase in the volume of knowledge (Mayer, B. O., 2018), but reducing the quality of its reflection, assimilation and value bases (Pushkarev, Y. V., Pushkareva, E. A., 2018c).

Modern trends in the informatization of science are associated with the following major transformations of the scientific sphere:

- with wide computerization and mathematization of Humanities;

- increasing the intelligence of automated research systems and increasing the number of workstations for researchers;

- inclusion of researchers in the world information computer network of databases and knowledge;

- increasing the role of computer modeling in scientific research, etc.

XLinguae, Volume 12, Issue 4, October 2019, ISSN 1337-8384, eISSN 2453-711X 


\section{Conclusions}

So, to summarize

1. The role of means of communication in the development of modern society is extremely high. There are active processes of formation of the global organization of socio-cultural space.

2. The emerging communication factors are directly dependent on the level of development of information-sharing tools and technologies. Modern society highly appreciates technological innovations, developed network of computer communications.

3. Communication factors have a direct impact on the development of social systems (education, science). The ability not only to technological, but also to social innovation, the ability to act effectively in a rapidly changing social environment are becoming important

4. For the development of modern communication, the primary role is played primarily by the education system. It is on the basis of developed education that it will be possible to develop infrastructure, to occupy competitive positions, on the one hand. On the other hand, education is the most important channel for broadcasting both general cultural values and values of national culture.

5. In the context of developing communication, today the most important element of the development of modern society is the level of development of its intellectual culture. Intellectual culture accumulates reproduces and creates special information in the form of a system of values as a special environment for the development of society.

\section{Bibliographic references}

AUER, R. A. 2015. Human capital and the dynamic effects of trade. Journal of Development Economics, vol. 117, pp. 107-118. DOI: https://doi.org/10.1016/j.jdeveco.2015.07.004

BROOKS, R. 2018. Higher education mobilities: a cross-national European comparison. Geoforum, vol. 93, pp. 87-96. DOI: https://doi.org/10.1016/j.geoforum.2018.05.009

CHOI, K.-H. - SHIN S. 2015. Population aging, economic growth, and the social transmission of human capital: An analysis with an overlapping generations model. Economic Modelling, vol. 50, pp. 138-147. DOI: https://doi.org/10.1016/j.econmod.2015.05.015

DIAZ-FERNANDEZ, M. - PASAMAR-REYES, S. - VALLE-CABRERA, R. 2017. Human capital and human resource management to achieve ambidextrous learning: a structural perspective. BRQ Business Research Quarterly, vol. 20, no. 1, pp. 63-77. DOI: https://doi.org/10.1016/j.brq.2016.03.002

GIZIENE, V. - SIMANAVICIENE, Z. 2015. The impact of human capital on labour market: Lithuanian case. Procedia - Social and Behavioral sciences, vol. 191, pp. 2437-2442. DOI: https://doi.org/10.1016/j.sbspro.2015.04.331

GOGAN, L. M. - ARTENE, A. - SARCA I. - DRAGHICI A. 2016. The impact of intellectual capital on organizational performance. Procedia - Social and Behavioral Sciences, vol. 221, pp. 194-202. DOI: https://doi.org/10.1016/j.sbspro.2016.05.106 GUREN, A. - HEMOUS, D. - OLSEN, M. 2015. Trade dynamics with sectorspecific human capital. Journal of International Economics, vol. 97, issue 1, pp. 126147. DOI: https://doi.org/10.1016/j.jinteco.2015.04.003

JEONG, M. 2015. Optimal policy in an economy with human capital where money is essential. Economics Letters, vol. 136, pp. 103-107. DOI: https://doi.org/10.1016/j.econlet.2015.09.016

KHOROSHILOVA, S. P. - KOSTINA, E. A. 2016. Cross-cultural study of the impact of short-term language courses abroad on language acquisition. Novosibirsk State 
Pedagogical University Bulletin, no. 4, pp. 108-118. DOI: http://dx.doi.org/10.15293/2226-3365.1604.10

KOSTINA, E. A. - HACKETT-JONES, A. V. - BAGRAMOVA, N. V. 2017. The impact of interlanguage on students' bilingual behaviour during the process of acquiring a foreign language. Novosibirsk State Pedagogical University Bulletin, no. 4, pp. 93-107. DOI: http://dx.doi.org/10.15293/2226-3365.1704.06

KOLYKHALOV, M. I. - PUSHKAREVA, E. A. 2018. Processes of globalization and regionalization in the development of modern society: Integration of research approaches in social and humanitarian knowledge. Novosibirsk State Pedagogical University Bulletin, vol. 8 (4), pp. 94-108. DOI: http://dx.doi.org/10.15293/22263365.1804 .06

LATUHA, O. A. 2018. Training leaders of organizations in sustainable development management. Novosibirsk State Pedagogical University Bulletin, vol. 8 (3), pp. 225 236. DOI: http://dx.doi.org/10.15293/2226-3365.1803.16

MARDAKHAEV, L. V. - EGORYCHEV, A. M. - VARLAMOVA, E. YU. KOSTINA, E. A. 2018. Development of linguo-cultural personality of future teachers within the educational environment of higher educational institutions. Novosibirsk State Pedagogical University Bulletin, no. 4, pp. 204-216. DOI: http://dx.doi.org/10.15293/2226-3365.1804.13 (In Russ.)

MAYER, B. O. 2018. On the clustering of cognitive learning theories. Novosibirsk State Pedagogical University Bulletin, vol. 8 (2), pp. 119-134. DOI: http://dx.doi.org/10.15293/2226-3365.1802.07

PASBAN, M. - NOJEDEH S. H. 2016. A review of the role of human capital in the organization. Procedia - Social and Behavioral Sciences, vol. 230, pp. 249-253. DOI: https://doi.org/10.1016/j.sbspro.2016.09.032

PISONOVA, M. 2016. Philosophical explication of requirements on the process of education - Novelty or Relic? XLinguae, vol. 9 (1), pp. 83-90. DOI: https://doi.org/10.18355/XL.2016.09.01.83-90

POGORLETSKAIA, I. I. 2016. Topical problems of correlation of universal and national values in contemporary societies. Knowledge. Understanding. Skill, no. 2, pp. 307-319. (In Russ.) Availale online: https://elibrary.ru/item.asp?id=26322856

PUSHKAREV, Y. V. -PUSHKAREVA, E. A. 2016b. Fundamental knowledge in the continuing education: methodology and axiology of the problem. Novosibirsk State Pedagogical University Bulletin, no. 1, pp. 87-98. DOI: http://dx.doi.org/10.15293/2226-3365.1601.08

PUSHKAREV, Y. V. - PUSHKAREVA, E. A. 2018b. Philosophical interpretation of knowledge and information: Knowledge value and information diversity in modern communication. XLinguae, vol. 11 (3), pp. 176-184. DOI: https://doi.org/10.18355/XL.2018.11.03.17

PUSHKAREV, Y. V. - PUSHKAREVA, E. A. 2018c. Formation of personality legal culture in the knowledge society: Conceptual foundations. Novosibirsk State Pedagogical University Bulletin, vol. 8 (6), pp. 73-86. DOI: http://dx.doi.org/10.15293/2226-3365.1806.05

PUSHKAREV, Y. V. - PUSHKAREVA, E. A. 2017b. The concept of intellectual potential development: the main dimensions and bases within the context of lifelong education (review). Novosibirsk State Pedagogical University Bulletin, no. 3, pp. 140-156. DOI: http://dx.doi.org/10.15293/2226-3365.1703.09

PUSHKAREV, Y. V. - PUSHKAREVA, E. A. 2018a. Human rights as a value of personal development in the knowledge society. Novosibirsk State Pedagogical University Bulletin, vol. 8 (3), pp. 80-91. DOI: http://dx.doi.org/10.15293/22263365.1803.06

PUSHKAREV, Y. V. - PUSHKAREVA, E. A. 2017a. Healthcare educational value for ensuring social and environmental sustainability (review). Novosibirsk State

XLinguae, Volume 12, Issue 4, October 2019, ISSN 1337-8384, eISSN 2453-711X 
Pedagogical University Bulletin, no. 5, pp. 157-178. DOI: http://dx.doi.org/10.15293/2226-3365.1705.11

PUSHKAREV, Y. V. - PUSHKAREVA, E. A. 2016a. Continuous education philosophy in the context of global culture development. Novosibirsk State Pedagogical University Bulletin, vol. 6 (3), pp. 60-67. DOI: http://dx.doi.org/10.15293/2226-3365.1603.06

RODRIGUEZ, D. - BUSCO, C. - FLORES, R. 2015. Information technology within society's evolution. Technology in Society, vol. 40, pp. 64-72. DOI: https://doi.org/10.1016/j.techsoc.2014.08.006

SHIELDS, R. 2016. Reconsidering regionalisation in global higher education: student mobility spaces of the European Higher Education Area. Compare: A Journal of Comparative and International Education, vol. 46 (1), pp. 5-23. DOI: https://doi.org/10.1080/03057925.2014.884348

SMAJS, J. 2016. On the principle of evolutionary ontology. Novosibirsk State Pedagogical University Bulletin, vol. 6 (1), pp. 78-86. DOI: http://dx.doi.org/10.15293/2226-3365.1601.07

ȘOPRONI, L. - T,OCA, C. 2017. The role of the economic borders in contemporary international relations. Studia Universitatis Babes-Bolyai. Studia Europaea, issue 2, pp. 121-134. DOI: https://doi.org/10.24193/subbeuropaea.2017.2.07

TZEREMES, N. G. 2014. The effect of human capital on countries' economic efficiency. Economics Letters, vol. 124, no. 1, pp. 127-131. DOI: https://doi.org/10.1016/j.econlet.2014.05.006

VLASYUK, N. N. - MAYER, B. O. 2016. Education for sustainable development: global and regional aspects. Novosibirsk State Pedagogical University Bulletin, vol. 6 (3), pp. 50-59. DOI: http://dx.doi.org/10.15293/2226-3365.1603.05

WAHLGREN, B. - MARIAGER-ANDERSON, K. - SØRENSEN, S. H. 2016. Expanding the traditional role of the adult education teacher - the development of relation-al competences and actions. Teaching and Teacher Education, vol. 60, pp. 303-311. DOI: http://dx.doi.org/10.1016/j.tate.2016.09.005

WOHLIN, C. - SMITE, D. - BREDE MOE, N. 2015. A general theory of software engineering: balancing human, social and organizational capitals. Journal of Systems and Software, vol. 109, pp. 229-242. DOI: https://doi.org/10.1016/j.jss.2015.08.009 YONEZAWA, A. - HORTA, H. - OSAWA, A. 2016. Mobility, formation and development of the academic profession in science, technology, engineering and mathematics in East and South East Asia. Comparative Education, vol. 52 (1), pp. 4461. DOI: https://doi.org/10.1080/03050068.2015.1125617

ZAHID, G. 2015. Globalization, nationalization and rationalization. Procedia - Social and Behavioral Sciences, vol. 174, pp. 109-114. DOI: https://doi.org/10.1016/j.sbspro.2015.01.633

Words: 3251

Characters: 23864 (13,26 standard pages)

assoc. prof. Yury V. Pushkarev

Novosibirsk State Pedagogical University

Novosibirsk

Russia

pushkarev73@mail.ru

assoc. prof. Elena A. Pushkareva

Novosibirsk State Pedagogical University

Novosibirsk

Russia

pushkarev73@mail.ru 